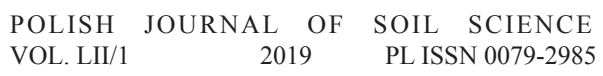

DOI: $10.17951 / \mathrm{pjss} / 2019.52 .1 .1$

\title{
RENATA KOŁODYŃSKA-GAWRYSIAK* \\ THE IMPACT OF PALAEORELIEF ON THE ORIGIN OF SOME CLOSED DEPRESSIONS IN LOESS AREAS IN THE LUBLIN UPLAND (EASTERN POLAND)
}

Abstract. Closed depressions (CDs) are common small forms occurring in the European loess belt. The age, origin and evolution of these forms is highly debated. Some CDs are reproduced in the loess cover. Their formation was directly influenced by the relief of sediments underlying the loess cover and varying in terms of age and origin. Two depressions of this type were documented within the thin ( $8 \mathrm{~m}$ ) loess covers in the Nałęczów Plateau and the Dubienka Depression, using the electrical resistivity method. The age of the reproduced forms varies. The CD in Sadurki formed during the Vistulian glaciation. The CD in the Horodło site was forming from the Odranian to the Vistulian glaciation.

Keywords: closed depressions, loess, palaeorelief, electrical resistivity profiles, Lublin Upland

\section{INTRODUCTION}

Closed depressions (CDs) are common forms occurring in the European loess belt. The age, origin and evolution of these forms is highly debated but not fully explained yet (Gillijns et al. 2005, Vanvalleghem et al. 2007, Etienne et al. 2011, Kołodyńska-Gawrysiak and Poesen 2017). Czarnecki and Lewartowska-Urbańska (1987) suggest that the formation of closed depressions in the Sandomierz Upland was influenced by the varied relief of sediments underlying the loess cover. CDs in the east of Poland are natural small landforms on the surface of the loess cover that was accumulating until 15,000-12,000 BP (Maruszczak 1976, 1980). They

* Faculty of Earth Science and Spatial Management, Maria Curie-Skłodowska University, Al. Kraśnicka 2cd, 20-718 Lublin, e-mail: renata.kolodynska-gawrysiak@poczta.umcs.lublin.pl 
are filled by soil-sediment sequences forming during the entire Holocene. The distribution of CDs in the east of Poland is uneven, which results from the direct and indirect (thermokarst) influence of local geological determinants impacting the formation of these forms (Kołodyńska-Gawrysiak et al. 2015, 2018). The main research objective is to assess the impact of the relief under the loess cover on the origin of some CDs in the loess areas of the Lublin Upland.

\section{METHODS}

Two representative CDs were chosen for detailed investigation. They are located in areas with a different geological structure under the loess cover. Two electrical resistivity profiles were made across each representative $\mathrm{CD}$ in order to examine the relief of sediments underlying the loess cover. These investigations were conducted using the Lund Imaging System (Loke 2004, Żogała et al. 2008, Żogała 2013) with electrode spacing every $5 \mathrm{~m}$ or $10 \mathrm{~m}$, and the measurement results were interpreted using the Res2D programme and taking topography into account (Instruction manual Res2Dinv, 2001). In the Sadurki site, the AB and CD profiles were $200 \mathrm{~m}$ and $300 \mathrm{~m}$ long respectively with electrode spacing every $5 \mathrm{~m}$. In the Horodło site, the $\mathrm{AB}$ and $\mathrm{CD}$ profiles were $350 \mathrm{~m}$ long with electrode spacing every $10 \mathrm{~m}$. The electrical resistivity measurements reached a depth of about $40 \mathrm{~m}$ in the Sadurki site and $70 \mathrm{~m}$ in the Horodło site. Electrical resistivity profiles were made and interpreted by Dr hab. Bogdan Żogała from the University of Silesia. Eight or nineteen shallow soil auger holes (thickness up to $8 \mathrm{~m}$ ) were bored in the studied sites and located in transects corresponding to electrical resistivity profiles. One deep drilling $(15 \mathrm{~m})$ with a mechanical soil probe was conducted in the bottom of each CD in order to determine the geological structure underneath the CDs. Soil horizons and sediment layers from soil auger holes were identified and documented in detail. The morphological properties of the sediment layers and soil horizons were also documented and described according to Guidelines for soil descriptions (FAO 2006). Data from 11 archive geological boreholes, obtained from the HYDRO Bank of the Polish Hydrogeological Survey, were also used in the study (www.pgi.gov.pl/psh/dane-hydrogeologiczne-psh/947-bazy-danych-hydrogeologiczne/9057-bankhydro.html). The borehole descriptions were analysed in detail in order to carry out the lithogenetic interpretation of sediments recorded in the individual geological profiles.

\section{STUDY AREA}

The CDs under study are located on the loess covers of the Lublin Upland (Eastern Poland) (Fig. 1). Both CDs under study are agriculturally used. The area of the CD in Sadurki is $4,382 \mathrm{~m}^{2}$, longer axis is $84 \mathrm{~m}$ and its depth is $1.2 \mathrm{~m}$; it lies 


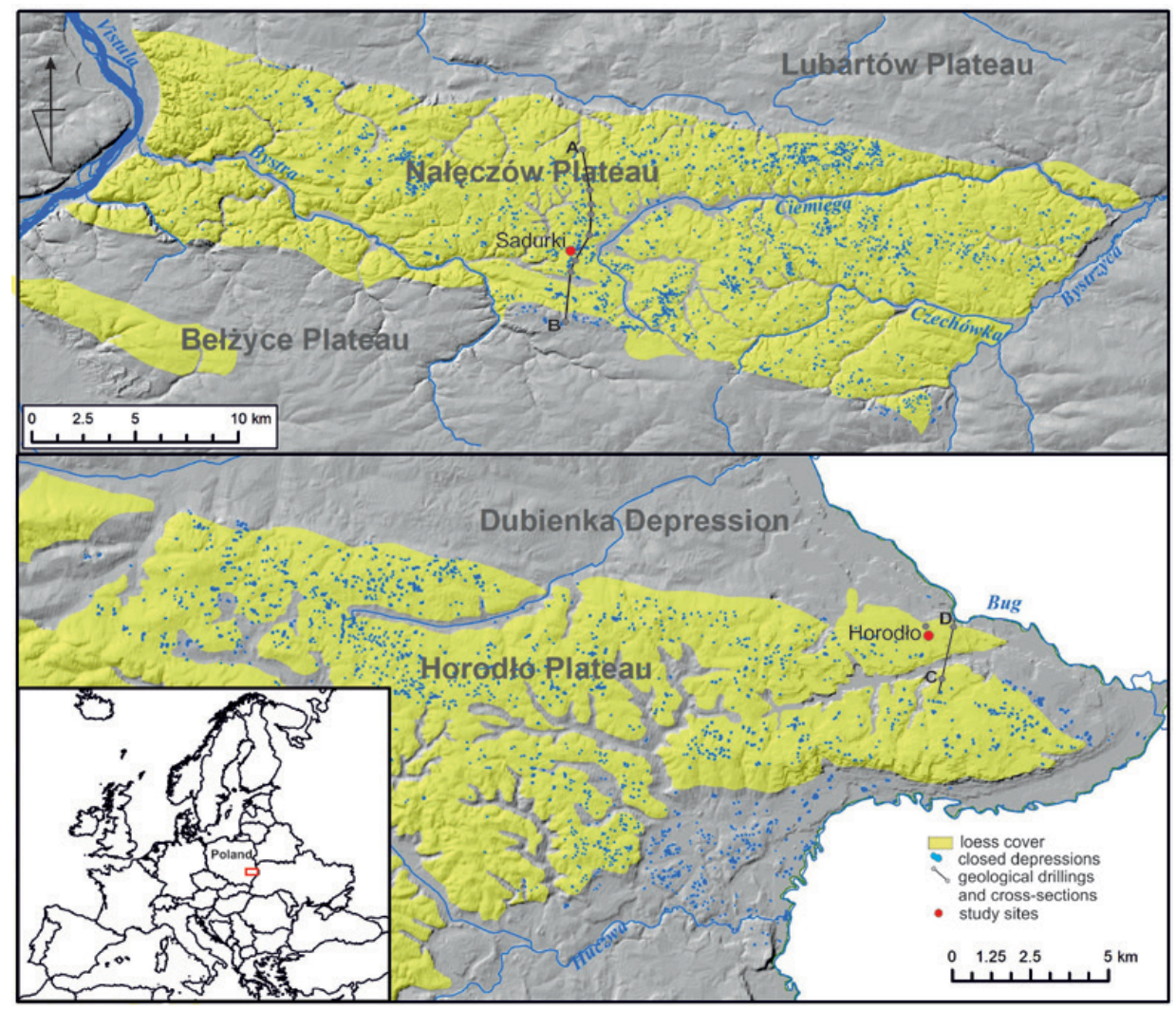

Fig. 1. Location of the study sites

in the Nałęczów Plateau. This CD is situated within a low watershed, separating the Ciemięga and Bystra valleys (Fig. 1). The land there rises to $210 \mathrm{~m}$ a.s.l. and features many CDs located between arch-shaped ridges a few metres high (Fig. 2A).
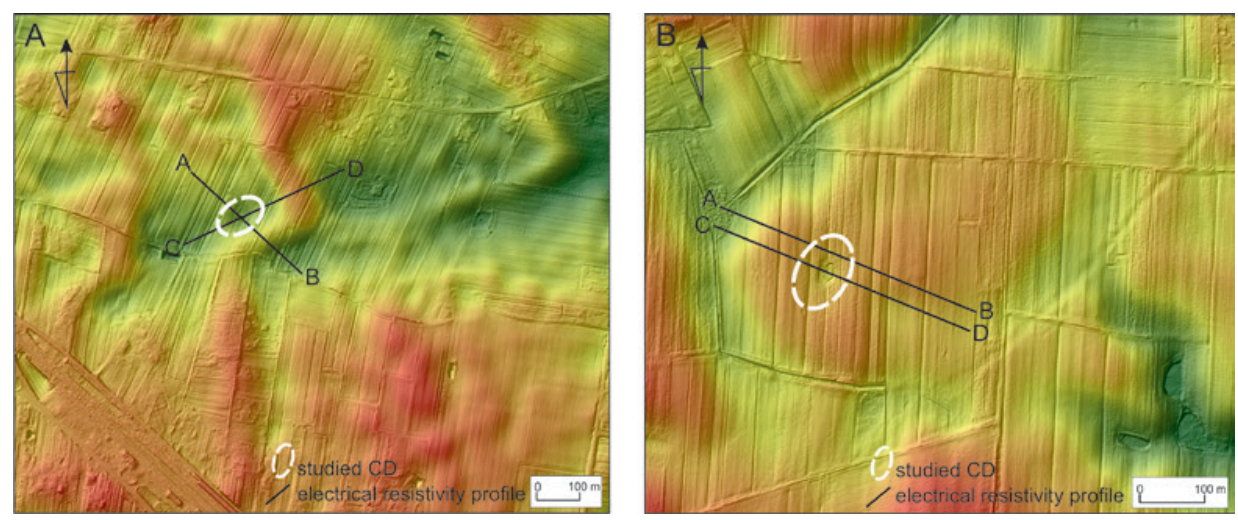

Fig. 2AB. Location of the electrical resistivity profiles in the studied CD in the Sadurki (A) site and the Horodło (B) site 
The area of the $\mathrm{CD}$ in Horodło is $12,400 \mathrm{~m}^{2}$, longer axis is $100 \mathrm{~m}$ and its depth is $1.25 \mathrm{~m}$; it is located in the Dubienka Depression in the immediate neighbourhood of the Horodło Plateau (Fig. 1). It lies at $200 \mathrm{~m}$ a.s.l., within a flat higher river terrace with loess cover (Dolecki 2010) with a small number of CDs; the terrace is dissected by shallow erosion-denudation valleys with wet floors (Fig. 2B).

\section{GEOLOGICAL CONTEXT OF THE STUDIED CDs}

The bedrock of the Nałęczów Plateau consists of Upper Maastrichtian (opokas, marly opokas, marls) and Palaeogene (limestones, gaizes and sandstones) calcareous rocks (Pożaryska 1967, Harasimiuk and Henkiel 1978, Harasimiuk,1980). The bedrock underlies a bipartite Pleistocene sediment complex. The lower part of this complex is made up of glacial deposits (glacial tills), glaciofluvial deposits (sands and gravels) and ice-marginal lake (limnoglacial) deposits (clayey loams, clays) from the Sanian (Elster) and Odranian (Saale 1) glaciations. The upper part is made up of loess (Harasimiuk and Henkiel 1978, Pożaryski et al.

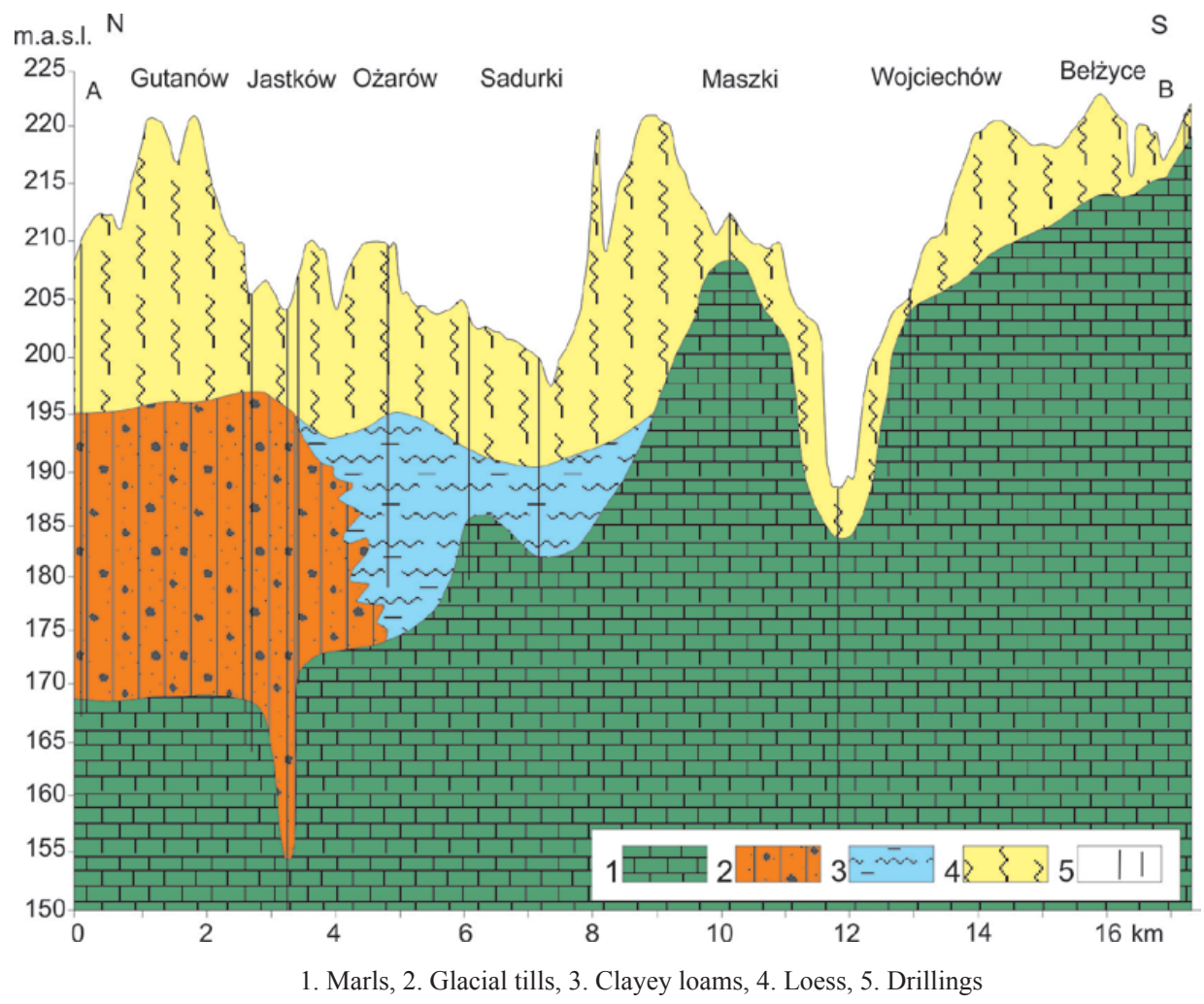

Fig. 3. Geological structure in the vicinity of the Sadurki site (after Kołodyńska-Gawrysiak et al. 2018) 
1994). Glacial tills from the Odranian (Saale 1) glaciation form a thick layer at the bottom of the loess. The accumulation relief after the recession of the Odranian (Saale 1) glaciation was characterised by the presence of hills made up of moraine tills and flat, wide depressions (probably dead-ice depressions) frequently filled with limnoglacial, clayey-loamy sediments. These forms, along with kame hills, were the features of the highly diverse relief of the marginal zone of the Odranian (Saale 1) glaciation, especially in the western part of this region and areas between the Bystra and Ciemięga rivers. North of the Ciemięga and Bystra valleys, there is a zone of head moraine hills made up of glacial tills with an average thickness $>15$ m (Kołodyńska-Gawrysiak et al. 2015, 2018).

In the Sadurki area, a several metres thick loess cover is underlain by a layer of carbonate clayey loams (Odranian limnoglacial deposits) whose thickness ranges from several to a dozen or so metres and which are underlain by glacial tills from the Odranian (Saale 1) glaciation or, directly, the bedrock (Fig. 3). The relief of clayey-loamy deposits is locally varied, and the elevation differences reach a few metres (Fig. 3).

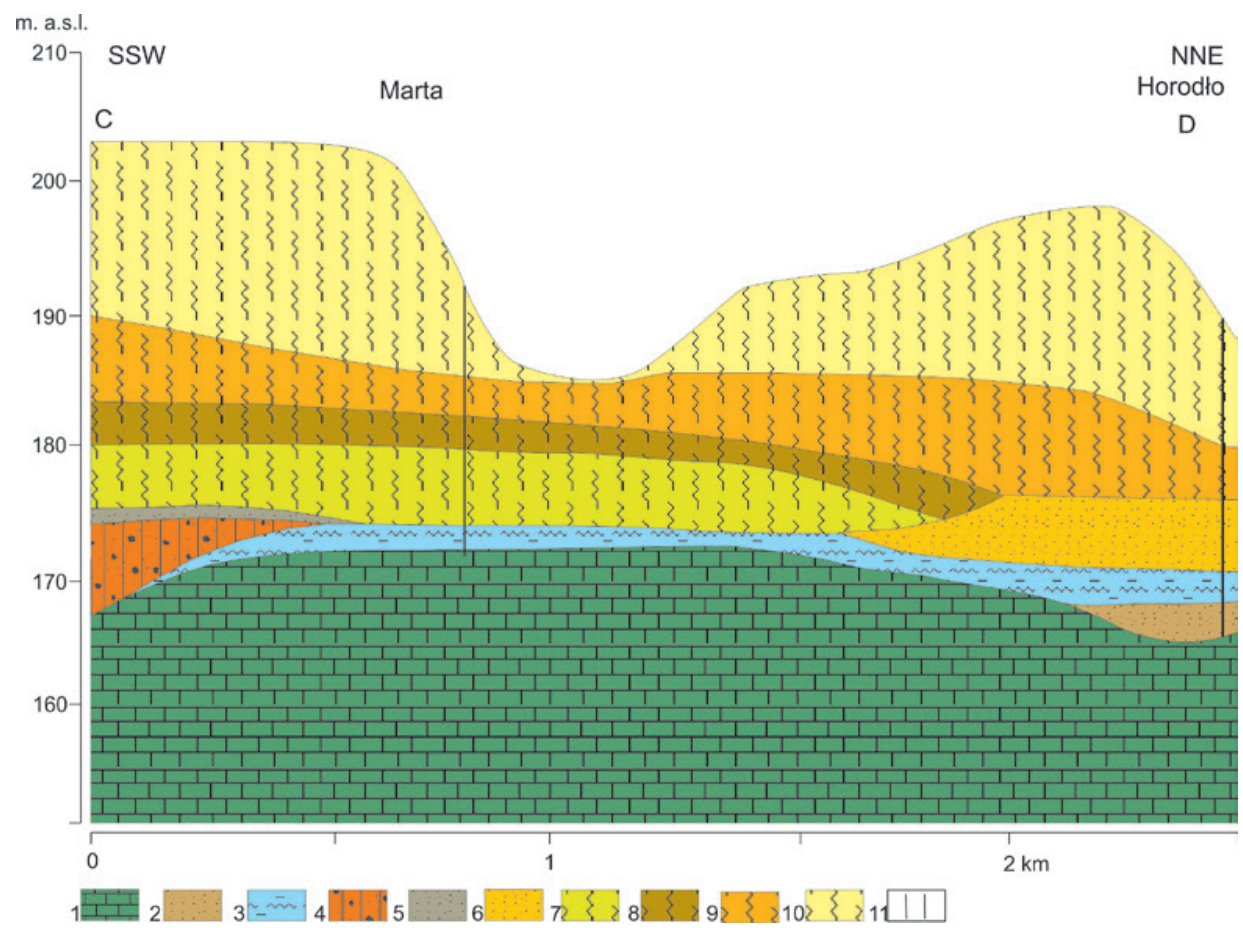

1. Campanian: marls; Sanian I glaciations, 2. Fluvioglacial sands and gravels, 3. Fluvioperiglacial loess-like muds, 4. Tills; Zbójnian interglacial, 5. Fluvial loamy sands with shells and molluscs, 6. Fluvial sands; Odranian glaciations, 7. Lower older loess of different facies and loess-like alluvial deposits, 8. Middle older loess of different facies; Wartanian glaciations, 9. Upper older loess of different facies; Vistulian glaciation, 10. Younger loess, 11. Drillings

Fig. 4. Geological structure in the vicinity of the Horodło site (after Dolecki 2010) 
The bedrock of the eastern part of the Horodło Plateau is made up of tectonically fractured Upper Cretaceous marls and marly limestones. The bedrock is overlain by glacigenic and interglacial deposits from the Elster glaciation (Dolecki $1995,2010)$. In turn, they are overlain by a complex of older loess from the Odranian glaciation (lowest - LSn, lower - LSd and middle older loess - LSs) and Wartanian glaciation (upper older loess - LSg), its thickness ranging from several to about a dozen or so metres (Fig. 4). Older loess is represented by various facies, which results in lithological differences between younger loess (LM) and older loess (LS) (Dolecki 1995). Younger loess from the Vistulian glaciation occurs in the top part of the Quaternary sediments (Fig. 4). Along with older loess, they are interbedded with fossil soils of varying stratigraphic status. The loess from the Vistulian glaciation is 12 to $14 \mathrm{~m}$ thick within the loess plateau tops; it becomes distinctly thinner at the peripheries. Younger loess locally disappears and older layers of the loess cover (LS) are exposed on the surface (Dolecki 2010).

\section{RESULTS}

\subsection{Geological structure of the studied CDs based on electrical resistivity profiles}

\subsubsection{Sadurki site}

The closed depression in Sadurki developed within a 8-10 $\mathrm{m}$ thick loess cover (Fig. 5). Calcareous loess was found on the slopes of the CD, at the depth of 70-250 cm. The top of the calcareous loess layer runs parallel to the current topography and descends rapidly below the lower sections of the slopes of the $\mathrm{CD}$. At the bottom of the $\mathrm{CD}$, calcareous loess was not found in the auger hole bored through whole loess cover. The loess cover is underlain by glaucous calcareous clayey loams (Fig. 5). The thickness of the clayey loams in the Sadurki

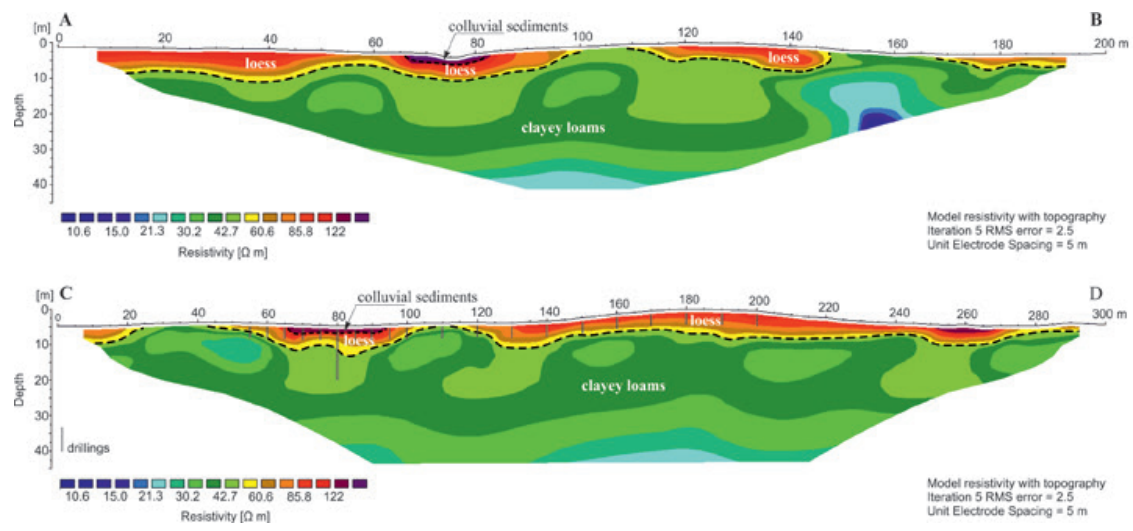

Fig. 5. Electrical resistivity profiles in the studied CD in Sadurki 
area is 10-20 m. The clayey loams lie on a bedrock composed of opokas and marls (Fig. 3). The top of the clayey loams is varied (Fig. 3).

The electrical resistivity profile suggests the existence of a depression on the surface of the clayey loams below the depression developed in the loess (Fig. 5). Elevations (ridges) made up of clayey loams are clearly visible in these profiles as well (Fig. 5). On these elevations under the loess cover, the thickness of the loess is the smallest. Beyond them, the thickness increases (Fig. 5). Loess partially fills the depressions in the older underlying sediments and form small dunes (Fig. 5). The original surface of the bottom of the studied CD is covered by a polygenetic Late Vistulian-Holocene fossil soil Ab-Bht-Bt1-Bt2$\mathrm{Bt} / \mathrm{C}-\mathrm{C}$ that developed on loess in-situ. Polygenetic soil identified in this CD seem to correspond well with the pedogenic model of evolution from the Early Holocene Chernozem to Luvisol, which started in the Atlantic period (Kühn et al. 2017). This soil was developing until its burial by colluvial sediments. The CD in Sadurki is filled with $100 \mathrm{~cm}$ thick Holocene colluvial sediments (Fig. 5). The Colluvisol Ap-Cg developed on these colluvia. According to classification of colluvial soils after Zádorová and Penížek (2018), this is Colluvisol type A.

\subsubsection{Horodło site}

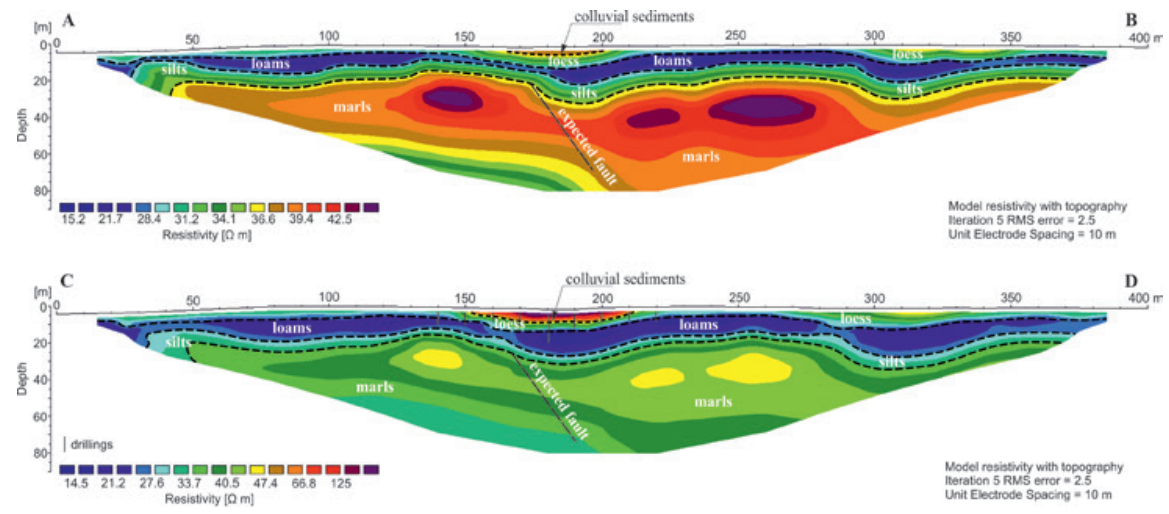

Fig. 6. Electrical resistivity profiles in the studied CD in Horodło

The closed depression in Horodło developed within a $8 \mathrm{~m}$ thick loess cover (Fig. 6). Calcareous loess was found on the slopes of the CD, at the depth of 50-200 cm. The top of the calcareous loess layer runs parallel to the current topography and descends rapidly below the lower sections of the slopes of the $\mathrm{CD}$. In the bottom of the CD, calcareous loess was not found in the auger hole bored through the entire loess cover $(8 \mathrm{~m})$. The loess cover is underlain by calcareous loams (Fig. 6). The thickness of the loams in the Horodło area reaches $15 \mathrm{~m}$. This layer probably corresponds to the following loess layers that are richer in the clay fraction: LMd - lower younger loess (25.5\% of clay), LSg 
- upper older loess ( $18.0 \%$ of clay), LSs - middle older loess ( $22.9 \%$ of clay) and LSd - lower older loess (22.0\% of clay), distinguished by Dolecki (1995, 2010) (Fig. 4). They are underlain by a 5 metre thick layer of silts (Fig. 6). They correspond to loess-like muds ( $44.0 \%$ of silt, $12.4 \%$ of clay, $18.0 \%$ of sand) from Sanian I glaciaciation, distinguished by Dolecki $(1995,2010)$ (Fig. 4). The silts lie on a bedrock composed of marls (Dolecki 2010) (Fig. 4). The top of the marls is varied. The electrical resistivity profile suggests the existence of depressions on the surface of the marls. One of such depressions in the marls is located under the studied CD (Fig. 6). The depression is filled with silts, loams and loess (Fig. 6). The original surface of the bottom of the $\mathrm{CD}$ is covered by a polygenetic Late Vistulian-Holocene fossil soil Ab-AB-Bg-B/C-C (Cambic Phaeozem) that developed on loess in-situ (WRB 2015). The CD in Horodło is filled with $100 \mathrm{~cm}$ thick Holocene colluvial sediments (Fig. 6). The Colluvisol Ap-Cg developed on these colluvia. According to classification of colluvial soils after Zádorová and Penížek (2018), this is Colluvisol type B.

\section{DISCUSSION}

The Sadurki site is located in the low watershed area between the Ciemiegga and Bystra valleys. The elevation of the land here reaches $210 \mathrm{~m}$ a.s.l. Towards the north, absolute elevations reach $229 \mathrm{~m}$ a.s.l. (Gutanów area) while towards the south, they reach $220 \mathrm{~m}$ a.s.l. (Kol. Miłocin and Maszki area). This area lies between the high Cretaceous escarpment of the Bełżyce Plain in the south and the culmination of the hills of the frontal moraine zone from the Odranian glaciation in the north (Fig. 3). It belongs to the marginal zone of the Odranian glaciation where, in areal downwasting conditions, accumulation land relief with many kame hills of varying size formed (Kołodyńska-Gawrysiak et al. 2015 , 2018). Broad and relatively flat depressions made up of marginal lake sediments extended between them. During the Vistulian glaciation, the area of the marginal lake probably constituted the source of loess dust. This is suggested by Harasimiuk (1987) whose investigations showed that the loess cover in the Nałęczów Plateau accumulated in conditions of short-distance transport and winds from various directions. At the same time, local stratigraphic variation of the Vistulian loess covers occurs in the Nałęczów Plateau, manifested, for instance, in the lack of LMn (lower younger loess) in certain loess profiles (Harasimiuk 1987). This suggests the local variation in the Vistulian depositional processes resulting in a temporal and spatial variation of the accumulation of the loess cover in the Nałęczów Plateau (Harasimiuk and Henkiel 1976, 1978). The varying dynamics of aeolian processes during the younger phases of the Vistulian loess deposition is evidenced by small accumulation forms visible on the surface of the thin loess covers of the area between the Ciemięga and 
Bystra rivers (e.g. Fig. 2A). The electrical resistivity profiles made in the Sadurki area show that the thin loess cover (probably from the later phases of loess accumulation) was superimposed on the morphology of the marginal lake plain comprising elevations (ridges) and depressions between them (Fig. 5). At least three origin scenario of these microforms underlain loess cover are possible: (1) The elevations can be accumulation forms determined by the presence of ridges of the underlying Cretaceous bedrock, overlain by marginal lake sediments (Fig. 3). Therefore, this type of microrelief can be inherited from the clayey loamy sedimentation period. (2) The formation of the microrelief could have been caused by the post-sedimentary dissection of the surface of the marginal lake, related to the formation of surface drainage (erosion-denudation forms). (3) The microrelief could have developed also as a result of deflation-corrasion processes during the older phases of the Vistulian loess formation.

The loess cover is the thinnest at the culmination of the ridges (several metres high) because they constituted an obstacle to the wind-blown dust (Fig. 5). Loess deposition occurred mainly behind those obstacles, partially also in the depressions (probably deflation depressions) between them (Fig. 5). Similar regularities in spatial distribution of the loess cover on the Nałęczów Plateau are reported by Harasimiuk and Henkiel $(1976,1978)$. The small forms of loess relief in the Sadurki area can be linked to dune-like morphology described in the literature. Loess ridges, referred to as "greda ridges" and resembling dunes have been described in central Europe (Leger 1990, Antoine et al. 2001). Longitudinal dunes extending in the direction of the prevailing winds in the Caspian and Black Sea coastal region are also described by Różycki $(1986,1991)$. Their origin is associated with the turbulent system of wind streams, conditioned by orographic obstacles.

A depression in rocks subject to karst processes, covered by a several metre thick layer of loess of varying age, was found in Horodło (Fig. 6). The studied depression is a form reproduced in the loess cover, superimposed on a depression of karstic origin (Fig. 6).

In many regions of the eastern part of the Lublin Plateau (Chełm Hills, Dubienka Depression and Western Polesie), there are forms of reproduced karst developed in mineral (fluvioglacial, periglacial and fluvial-periglacial) deposits of varying thickness, overlying the Upper Cretaceous carbonate rocks. They developed in different phases of the Upper Quaternary (Dobrowolski et al. 2010). According to Maruszczak (1966a), closed depressions reproduced in the thin loess covers predominate in the Hrubieszów Basin, a dozen or so kilometres south of the studied CD. The bedrock there, subject to karstic processes, is made up of rocks of the same age and type as those in the Horodło Plateau and in the Dubienka Depression. These are primarily marly limestones, marls and chalks from the Upper and Lower Maastrichtian (Maruszczak 1966a, Har- 
asimiuk 1980, Dolecki 1995). According to Maruszczak (1966b), some of the reproduced forms can originate from the Odranian-Wartanian glaciations.

Numerous karst forms, several metre deep and reproduced in the cover of the deposits not subject to karst processes, mainly sandy and sandy-clayey, were documented in the Chełm Hills by Harasimiuk (1975). Numerous Holocene karst depressions, up to $300 \mathrm{~m}$ in diameter and up to $4 \mathrm{~m}$ thick, reproduced in Odranian glacigenic (mainly glaciofluvial) deposits, occur in the Wielun Upland (Kobojek and Nalej 2008).

According to Dobrowolski (1998), the development of karst forms in marls and chalks in the Lublin Upland depends on the density of fractures in the rocks. Karst forms develop most intensively in zones corresponding to weathering cracks, joints and tectonic faults (Dobrowolski 1998). Changes in resistivity found beneath the studied closed depression in the electrical resistivity profile followed a pattern indicative of tectonic fault-type structures (Porres-Benito et al. 2016, Seminsky et al. 2016, Szalail et al. 2018), which suggests that the form in the marls developed in a tectonic fault zone.

The age of the studied reproduced CDs is varied and difficult to determine with precision, because of their formation in several stages. The lower boundary of the development of the reproduced forms is determined by the age of the fossil forms under the loess (not younger than the oldest sediments filling the forms). The final stage of the formation of the studied CDs corresponds to the final stages of the formation of the loess cover (15-12 ka BP). The CD in the Sadurki site probably formed in the Vistulian while the CD in Horodło formed during the Odranian-Vistulian glaciations.

\section{CONCLUSIONS}

The investigations showed that the relief of sediments underlying the loess cover directly influenced the formation of some CDs in the loess area of the Lublin Upland. The presence of depressions under the loess enabled the formation of depressions reproduced in the loess cover. These forms were identified in areas where thin loess covers, not more than a few metres thick, occur. Depressions under the loess can have different origins depending on the type of rock, conditions of their deposition and morphogenesis in the period before or during the deposition of the loess cover. Depressions documented under the loess are probably of karst and deflation origin. The age of the forms reproduced in the loess is varied. The CD in the Sadurki site formed in the Vistulian glaciation. The CD in the Horodło site was forming from the Odranian to the Vistulian glaciation. 


\section{ACKNOWLEDGEMENTS}

The research was financially supported by the National Science Centre grant No. 2012/07/B/ST10/04164, PB-B-12-287-00-13: "The origin and evolution of closed depressions in the loess areas in the Lublin Upland and their importance for the reconstruction of postglacial morphogenesis of the loess cover".

\section{REFERENCES}

[1] Antoine, P., Rousseau, D.-D., Zöller, L., Lang, A., Munaut, A-V., Hatte, Ch., Fontugne, M., 2001. High-resolution record of the last Interglacial-glacial cycle in the Nussloch loess-palaeosol sequences, Upper Rhine Area, Germany. Quaternary International, 76/77: 211-229.

[2] Czarnecki, R., Lewartowska-Urbańska, M., 1987. Closed depressions in the vicinity of Sandomierz (in Polish). Przegląd Geograficzny, LIX(3): 385-397.

[3] Dobrowolski, R., 1998. Structural conditions of recent karst relief development in the middle Wieprz and Bug interfluve (in Polish). Wydawnictwo UMCS, Lublin, 88 pp.

[4] Dobrowolski, R., Ziółek, M., Bałaga, K., Melke, J., Bogucki, A., 2010. Radiocarbon age and geochemistry of the infillings of small closed depressions from Western Polesie (Poland SE, Ukraine NW). Geochronometria, 36: 39-46.

[5] Dolecki, L., 1995. Lithology and stratigraphy of the loess sediments in the south-eastern part of the Lublin Upland (in Polish). Wydawnictwo UMCS, Lublin, 169 pp.

[6] Dolecki, L., 2010. Stratigraphy and main lithological features of loess formations in the south-eastern part of the Lublin Upland (SE Poland). Annales UMCS, 65(1): 7-42.

[7] Etienne, D., Ruffaldi, P., Goepp, S., Ritz, F., Georges-Leroy, M., Pollier, B., Dambrine, E., 2011. The origin of closed depressions in Northeastern France: A new assessment. Geomorphology, 126: 121-131.

[8] Gillijns, K., Poesen, J., Deckers, J., 2005. On the characteristics and origin of closed depression in loess-derived soils in Europe - a case study from central Belgium. CATENA, 60: 43-58.

[9] Guidelines for soil descriptions, fourth edition. Food and Agriculture Organization of the United Nations, Rome, 2006.

[10] Harasimiuk, M., 1975. The development of the relief of the Chetm Hills in the Tertiary and Quaternary (in Polish). Prace Geograficzne IG PAN, 115: 94 pp.

[11] Harasimiuk, M., 1980. The structural relief of the Lublin Upland and Roztocze (in Polish). UMCS, Lublin, 136 pp.

[12] Harasimiuk, M., 1987. Lithologic Properties as Indices of the Sedimentation Conditions of the Vistulian Loesses in the Eastern Part of the Natęczów Plateau (SE Poland). Annales UMCS, sec. B, 41(11): 179-202.

[13] Harasimiuk, M., Henkiel, A., 1976. Peculiarities of the loess cover in the western part of the Nałęczów Plateau (in Polish). Quaternary Research in Poland, t. 18. Wyd. Geol.: 177-181.

[14] Harasimiuk, M., Henkiel, A., 1978. The influence of geological conditions and the relief under loess cover on the loess relief in the western part of the Natęczów Plateau (in Polish). Annales UMCS, sec. B, 30(31): 55-80.

[15] Kobojek, S., Nalej, M., 2008. Reproduced karst landforms in the southern part of the Wielun Upland (in Polish). Landform Analysis, 9: 247-250.

[16] Kołodyńska-Gawrysiak, R., Harasimiuk, M., Chabudziński, Ł., Jezierski, W., Telecka, M., 2015. Geological conditions of the distribution of closed depressions in the Natęczów Plateau (Lublin Upland, E Poland): Are they an origin determinant? Landform Analysis, 29: 9-18. 
[17] Kołodyńska-Gawrysiak, R., Poesen, J., 2017. Closed depressions in the European loess belt - natural or anthropogenic origin? Geomorphology, 288: 111-128.

[18] Kołodyńska-Gawrysiak, R., Harasimiuk, M., Chabudziński, Ł., Jezierski, W., 2018. The importance of geological conditions for the formation of past thermokarst closed depressions in the loess areas of Eastern Poland. Geological Quarterly, 62(3): 685-704

[19] Kühn, P., Lehndorff, E., Fuchs, M., 2017. Lateglacial to Holocene pedogenesis and formation of colluvial deposits in a loess landscape of Central Europe (Wetterau, Germany). CATENA, 154: 118-135.

[20] Leger, M., 1990. Loess landforms. Quaternary International, 7: 53-61.

[21] Loke, M.H., 2004. Tutorial: 2-D and 3-D electrical imaging surveys. Available at: www. geoelectrical.com

[22] Maruszczak, H., 1966a. Karst phenomena on the Upper Cretaceous rocks in the Vistula and Bug interfluve (in Polish). Przegląd Geograficzny, 38(3): 339-370.

[23] Maruszczak, H., 1966b. The problems of the origin and age of the Łęczyńsko-Włodawskie lakes (in Polish). Biul. LTN, sec. D, 5(6): 31-37.

[24] Maruszczak, H., 1976. Loess stratigraphy of south-eastern Poland. Biuletyn Instytutu Geologicznego, 297: 135-175.

[25] Maruszczak, H., 1980. Stratigraphy and chronology of the vistulian loess in Poland. Quaternary Studies in Poland, 2: 57-76.

[26] Porres-Benito, J.A., Ibanez, S.J., Ortiz-Palacio, S., López-Ausín, V., 2016. Fractures location on karstified limestone surfaces by Electrical Resistivity Tomography Characterization. In: Geotechnical and Geophysical Site Characterisation 5, B.M. Lehane, H.E. Acosta-Martínez, R. Kelly (eds.), Australian Geomechanics Society, Sydney, Australia.

[27] Pożaryska, K., 1967. Cretaceous-Tertiary transition beds in Poland (except for the Carpathians). Geological Quarterly, 11(3): 661-672.

[28] Pożaryski, W., Maruszczak, H., Lindner, L., 1994. Chronostratigraphy of Pleistocene deposits and evolution of the Middle Vistula River Valley with particular attention to the gap through the South Polish Uplands. Prace Państwowego Instytutu Geologicznego, 147: 1-58.

[29] Różycki, S.Z., 1986. Loess-type dust deposits in the world, their distribution and origin. Studia Geologica Polonica, 85: 193 pp.

[30] Różycki, S.Z., 1991. Loess and loess-like deposits. Ossolineum, Wrocław, 187 pp.

[31] Seminsky, K.Zh., Zaripov, R.M., Olenchenko, V.V., 2016. Interpretation of shallow electrical resistivity images of faults: Tectonophysical approach. Russian Geology and Geophysics, 57: 1349-1358.

[32] Szalail, S., Kovács, A., Kuslits, L., Facskó, G., Gribovszki, K., Kalmár, J., Szarka, L., 2018. Characterisation of fractures and fracture zones in a carbonate aquifer using electrical resistivity tomography and pricking probe methods. Journal of Geoscience and Environment Protection, 6: 1-21.

[33] Vanwalleghem, T., Poesen, J., Vitse, I., Bork, H.R., Dotterweich, M., Schmidtchen, G., Deckers, J., Lang, A., Mauz, B., 2007. Origin and evolution of closed depression in central Belgium, European loess belt. Earth Surface Processes and Landforms, 32: 574-586.

[34] World Reference Base for Soil Resources 2014, update 2015. World Soil Resources Reports No. 106, FAO, Rome, 192 pp.

[35] Zádorová, T., Penížek, V., 2018. Formation, morphology and classification of colluvial soils: A review. European Journal of Soil Science, 69: 577-591.

[36] Żogała, B., Dubiel, R., Lewandowski, J., Zuberek, W.M., Gąska, G., 2008. Application of resistivity imaging method for investigation of geologic structure of Pleistocene sediments. Acta Geodynamica et Geomaterialia, 5(2): 177-183.

[37] Żogała, B., 2013. Geoelectric methods in the study of soils contaminated with oil derivatives (in Polish). Monograph. Wydawnictwo UŚ, Katowice. 